\title{
Erratum to: Solidarity, justice, and recognition of the other
}

\author{
Ruud ter Meulen ${ }^{1}$
}

Published online: 23 February 2017

(C) Springer Science+Business Media Dordrecht 2017

\section{Erratum to: Theor Med Bioeth (2016) 37:517-529 DOI 10.1007/s11017-016-9387-3}

The author would like to add the following acknowledgement to this article.

Acknowledgements His residential fellowship at the Brocher Foundation was supported by a Grant by the Wellcome Trust (WT104688MA) which helped the author to pay the costs of the replacement of his teaching duties during this fellowship as well as the travel costs to Geneva (and some other costs).

The online version of the original article can be found under doi:10.1007/s11017-016-9387-3.

Ruud ter Meulen

r.termeulen@bristol.ac.uk

1 Centre for Ethics in Medicine, School for Social and Community Medicine, University of Bristol, Canynge Hall, 39 Whatley Road, Bristol BS8 2PS, UK 